\title{
„SZTUKA NIEFORMALNEGO”. \\ ANTROPOLOGICZNE POJĘCIE WĘDRUJĄCE ${ }^{1}$
}

Tomasz Rakowski

Uniwersytet Warszawski

W pracy tej chcę pokazać, w jaki sposób antropologiczne rozumienie sfery nieformalności - spontanicznych i skomplikowanych mechanizmów współdziałania społecznego - rozwija się pod wpływem kontekstu badawczego. Wprowadzam tutaj pojęcie „sztuki nieformalnego”, w którym rozpoznawane moga być zarówno kulturowe uwarunkowania współpracy, jak i samoorganizacji społecznej. Pokazuję następnie, jak zmieniał się charakter tego pojęcia w badaniach, które odnoszą się do rzeczywistości potransformacyjnej Polski i szerzej - Europy Środkowo-Wschodniej, do byłych obszarów Związku Sowieckiego, ale przede wszystkim do współczesnej Mongolii.

Punktem wyjścia są moje rozważania dotyczące polskich przemian po roku 1989. Zajmuje mnie szczególnie to, co jako działanie nieformalne i balansujące na granicy prawa było rozpoznawane przez badaczy i publicystów jako balast na drodze do właściwego rozwoju społecznego. Szara strefa zatrudnienia, prace na czarno i wszelkie nieoficjalne sposoby radzenia sobie, wiązanie końca z końcem - to wszystko było wówczas niemal powszechnym doświadczeniem. Napotykałem te zjawiska w wielu moich badaniach wśród ludzi ubożejących w latach 90. i później, szczególnie w latach 2002-2006, kiedy wskaźniki bezrobocia i zubożenia były najwyższe w powojennej historii Polski (Rakowski 2009). Starałem się wtedy pokazać, że środowiska tych ludzi, wbrew wyobrażeniom „defektu” w ich wyposażeniu kulturowym, racjonalnie reagowały na tak trudną sytuację oraz że to właśnie wtedy wyraźnie wzmacniały się więzi społeczne, zobowiązania

1 Tekst został przygotowany w ramach realizacji projektu badawczego MNiSW/NCN, NN 109 180440, nr umowy 1804/B/H03/2011/40. 
w kręgach rodzinno-sasiedzkich i w kręgu bliskich znajomych (wzmacniały się także sieci przysług i znaczenie tego, co można nieformalnie ,załatwić”), co miało też pewną ciagłość socjologiczną i historyczną.

W moich badaniach starałem się przede wszystkim jednak pokazać, że w tego typu wyposażeniu społecznym można zobaczyć też coś niezwykle ważnego i na swój sposób pozytywnego, podmiotowego, związanego z przebudowywaniem się i rekonstruowaniem współczesnych społeczeństw. Łączy się to z elementami samoorganizacji i spontanicznego życia społecznego. Co więcej, aktywności te, mimo że są też często osia wieloletnich konfliktów społecznych, to mogą być potraktowane jako sytuacje, w których kręgi te powstaja jednocześnie poza państwem, poza instytucjami, jednocześnie oddolnie je wypełniając. W ten sposób tworzą się także pewne własne, oddolne idiomy czy formy antropologicznie rozumianej obywatelskości - przeciwstawiającej się abstrakcyjnie konstruowanym, normatywnym wzorcom społeczeństwa obywatelskiego ${ }^{2}$. Jednocześnie są to jednak też działania często ukryte, zamknięte, w pewnym stopniu związane z lokalnymi grami władzy, konkurencji, budowania pozycji, co wiąże się w ogóle z pewną pozaoficjalną sztuką działania nieformalnego.

Można by nawet stwierdzić, że praktyki te to wręcz także pewna niejawna forma egzystowania państwa. Nie są one zatem tylko częścią jakiejś sformalizowanej i zinstytucjonalizowanej ramy, ładu organizacyjnego, ale przede wszystkim formą realizowania się państwa rozumianego również jako działanie żywiołowe i oddolne. Co ciekawe, to oddolne działanie powstaje zwykle w kontrze do państwowych uwarunkowań, do niespełniania przez państwo podstawowych zadań czy też do jego nadmiernej funkcji kontroli. W tym ujęciu państwo jest zatem, jak pisała Begona Aretxaga (2003), pewną oddolną siłą tworząca reguły społeczne, która zawieszona jest w wewnętrznej, „subiektywnej dynamice” podmiotów. W pewnym sensie jest to sposób działania, w którym społeczne regulacje są jednocześnie wyobrażane, pomijane i przekraczane i w którym pojawia się pewna swoboda w omijaniu i unieważnianiu tych regulacji, zarówno w realny, jak i wyobrażony sposób. To zatem pewna władza podmiotów do różnicowania tego, co monolityczne i regulacyjne, a co następnie pozwala też na nasycanie praktyk omijania regulacji społecznych aktualnymi, głębokimi znaczeniami ${ }^{3}$.

\footnotetext{
${ }^{2}$ O czym pisali Chris Hann (zob. Hann 1996) i Michał Buchowski, odwołując się m.in. do osobistego udziału w wielkopolskich Ludowych Zespołach Sportowych (zob. Buchowski 1996).

${ }^{3}$ To nie tylko forma nielegalnego, nieformalnego działania, lecz także praktyka komunikacyjna, tworząca znaczenia i przetwarzająca je na wiele sposobów (Coombe 2005: 114; Linstroth 2010).
} 
Co istotne, to co nieformalne łączy się tutaj nieustannie ze sposobem wyobrażania życia społecznego - takiego, jakie powinno być i do jakiego podmioty społeczne żywiołowo dążą i jakie wytwarzają. Określeń „sztuka nieformalnego" albo „to, co nieformalne” używam tutaj w możliwie szerokim ujęciu, odnosząc je do sfery pewnej społecznej intymności, pojawiającej się w różnych momentach transformacji współczesnych społeczeństw. Szukam zatem kolejnych pojęć i idiomów dla tego, co jest działaniem nieformalnym, spontanicznym, odginającym regulacje prawne, i nie chodzi mi tutaj o mechanizmy czy procesy charakterystyczne dla samej „ekonomii nieformalnej", ale raczej o odnajdywanie pojęć dla tego, co społeczne, co wyobrażane i dynamizowane poprzez to, co nieformalne.

To dynamiczne i spontaniczne pole wytwarzane zarówno wewnątrz państwa, jak i na jego pograniczach, w obszarach alternatywnych, nieformalnych regulacji, jest więc w centrum uwagi. Jest to społeczna „sztuka nieformalnego" (the art of the informal ${ }^{4}$ ) - sztuka dekodowania, odczytywania i transformowania znaczeń życia społecznego to kluczowa kulturowa forma, którą można rozumieć jako zinternalizowaną, często bardzo bogatą wiedzę podmiotów o tym, jak działać i jak rozumieć to, co pojawia się na granicach formalnych regulacji ${ }^{5}$. Piszę o tej oddolnej, ,,subiektywnej dynamice” w odniesieniu do różnych obszarów i do różnych przykładów. Są to praktyki, zjawiska i doświadczenia społeczne, które napotykałem w środowiskach ludzi odbudowujących swój świat po utracie pracy i przywilejów społecznych w Polsce potransformacyjnej oraz w badaniach współczesnych wspólnot wiejskich. Odwołuję się także do antropologicznych badań obszarów poradzieckich. Przede wszystkim opisuję tutaj jednak te formy działania na podstawie ostatnich badań prowadzonych w Mongolii, poświęconych sposobom budowania sukcesu i lokalnego rozwoju wśród nowych ałtajskich biznesmenów, kupców i urzędników („nowych pasterzy”). To przejście od polskich doświadczeń do złożonych kontekstów mongolskich jest pewną drogą poznawczą, w której na różnych poziomach

\footnotetext{
${ }^{4}$ Użyłem po raz pierwszy tego pojęcia, pisząc o doświadczeniach transformacyjnych wałbrzyskich górników (Rakowski 2015).

${ }_{5}^{5}$ W ten sposób to jednocześnie świat bliski temu, do czego odnosił się Michael Herzfeld (2007), kiedy wspominał o komunikowaniu nieformalnej, bogatej wiedzy o zażyłości kulturowej, właśnie o pewnych niejawnych, a często wstydliwie ukrywanych „,cichych” umiejętnościach budowania i rozumienia tego, co społeczne. O takiej bogatej w dekodowanie i transformowanie znaczeń „poetyce społecznej" obywateli państwa peryferyjnego pisał na podstawie swoich badań m.in. greckich pasterzy. Podobnie pisał o sferze tego, co nieformalne i wstydliwie ukrywane, jako o poetyce i polityce gestu, tj. o nieformalnej, bogatej znaczeniowo gestykulacji (Herzfeld 2009), dobrze ukrywanej, ale wiodącej niejako na skróty do świata rozpoznań społecznych, świata „bycia razem” i zarazem „bycia zorientowanym” wśród mieszkańców miejskich kwartałów we współczesnym Rzymie.
}

\section{/ 192 STANRZECZY 1[10]/2016}


napotykam konieczność tworzenia nowych, zmieniających się pojęć zdolnych uchwycić i zidentyfikować sferę ,sztuki nieformalnego”. Są to pojęcia przemieniające się, wędrujące, związane z lokalnymi kontekstami, ale często kluczowe, jak uważam, dla zrozumienia wielu procesów przebudowy współczesnych społeczeństw.

\section{/// Poza wyobrażenia „obciążenia modernizacyjnego”: od ekonomii nieformalnej do sztuki nieformalnego}

Sfera tego, co nieformalne, w pewnym sensie staje się bardziej widoczna w warunkach gwałtownej transformacji. Nieformalne sposoby radzenia sobie w ramach zarówno prowadzenia przedsięwzięć biznesowych i instytucjonalnych, jak i prowadzenia zwykłego, codziennego życia są w ten sposób znakiem rozpoznawczym najnowszej historii krajów w Europie Środkowo-Wschodniej przechodzących transformacje po socjalizmie. Lata 90. w tym obszarze to czas wprowadzania nowych zasad, prawa, porządku fiskalnego, wolności gospodarczej i dla wielu też - gwałtownego zubożenia. To wtedy również w krajach takich jak Polska, Rumunia czy Ukraina, ale także - co pokazują studia - na obszarach poradzieckich w Azji, pojawiła się niemal wszędzie widoczna sfera pozaprawnego sposobu radzenia sobie, rozwijania biznesu, odnoszenia sukcesu czy po prostu - zdobywania pracy (Humphrey 2010, Henig, Makovicky 2016, Kideckel 2002, Knudsen, Frederiksen 2015, Ledeneva 1998, 2006, Yurchak 2002). Jednocześnie zdobyto wiedzę o nowych zjawiskach pozainstytucjonalnego formowania się grup, nieformalnych struktur, organizujących się na nowo ludzi. Z jednej strony przyszła albo raczej stała się widoczna przestrzeń gospodarki nieformalnej, z drugiej - nowe formy współdziałania, organizowania się grup lobbujących na rzecz swoich interesów, „przechwytujących” nowe, potransformacyjne i neoliberalne regulacje prawne. W świecie, który wyłonił się po demontażu socjalizmu, ujawniła się zatem z nową siłą sfera tego, co pozostaje poza regulacja państwa i jego aparatem biurokratycznym, choć nie zawsze poza tym, co dla państwa jest „widoczne”.

Nie znaczy to jednak, że gospodarki nieformalnej nie znajdziemy w zupełnie innych obszarach, w sensie historycznym i socjologicznym. $\mathrm{Na}$ przykład, jak pokazywał Keith Hart $(2005,2008)$, nawet ideologie wolnego rynku czy nawet strategie międzynarodowych agencji rozwojowych, projektowanych dla globalnego Południa, też zawierają w sobie założenia owego cichego, nieformalnego działania ekonomicznego. Ekonomia nieformalna, którą Hart zdefiniował w latach 70. jako nieregulowana, „cichą” praktykę 
gospodarcza, może być więc wstępnie uznawana za sytuację, w której państwa wycofują się z założenia nadzoru nad transakcjami ekonomicznymi, jak w przypadku zakładanej wcześniej polityki, np. wolnego handlu, albo w sposób bardziej przygodny, nieintencjonalny, jak w przypadku często spontanicznych procesów transformacji systemowej. Nieformalne sfery działania moga zatem odsłonić zarówno mechanizmy dające impuls do rozwoju wolnego rynku w krajach Północy, jak i te, leżące u podstaw nieregulowanych, nielegalnych transakcji, takich jak: łapówkarstwo, przemoc, ciche presje czy wymuszenia, szczególnie często opisywane w obszarach poradzieckich (Humphrey 2010). W ten sposób pojęcie sfery nieformalności może być jednak atrakcyjne poznawczo - obejmuje bowiem zarówno pozytywne, jak i negatywne zjawiska w życiu społecznym; choć nieprecyzyjne, jednocześnie umożliwia włączenie „sztuki nieformalnego” do wielu abstrakcyjnych modeli antropologicznych.

Nie zmienia to faktu, że gospodarka nieformalna w ujęciach i teoriach ekonomicznych może być przynajmniej wstępnie dość precyzyjnie określana i mierzona. Przy czym nawet w tych ujęciach już po chwili okazuje się, że uchwycenie jej zasięgu i jej konkretnych mechanizmów jest jednak bardzo trudne i obarczone znacznym ryzkiem błędu (Przychodzeń J., Przychodzeń K. 2009: 76). Działania nieregulowane, nieoficjalne ujmowane są na ogół w różne kategorie i określane za pomocą terminów i pojęć nakładających się na siebie wzajemnie, przynajmniej w dużej części. Używa się więc pojęć: ekonomia, gospodarka czy działalność „,nieformalna”, „nieobserwowalna”, „nierejestrowana” lub „niezgłaszana”, „gospodarka cienia”, „gospodarka drugiego obiegu”, ,ukryta”, ,podziemna”, oraz pojęcia „,szara strefa" (Cichocki 2006, Lapiński, Peterlik, Wyżnikiewicz 2014) i w sensie ekonomicznym odnosza się te terminy do perspektywy i aktywności instytucji regulujących/rejestrujących, do przedsiębiorstw i pracodawców czy w końcu do perspektywy pracujących i samego stosunku zatrudnienia. $\mathrm{Na}$ różne sposoby próbowano uporządkować wiedzę o tych zjawiskach ${ }^{6}$, moż- $^{-}$ na jednak zauważyć, że sam podział na sferę formalnych regulacji i pozaformalnych działań jest w wielu momentach mylący (Kanbur 2009). Wskazują też na to badacze gospodarek nieformalnych prowadzących badania w ramach antropologicznej krytyki rozwoju, którzy pokazuja, że substan-

\footnotetext{
${ }^{6}$ Zbigniew Galor (2011) za Kazimierzem Sową odwołuje się na przykład do ich trzech wymiarów: ekonomicznego (szacowanie wskaźników gospodarczych), społeczno-politycznego (mechanizmy publicznego i prywatnego uspołecznienia) czy antropologicznego (relacja na poziomie „ludzkim”, stosunek do pracy, do instytucji itd.), przy czym badacz wskazuje na oswajanie, uelastycznianie i czynienie czytelnym procesów pracy z punktu widzenia podmiotów zaangażowanych w działanie.
} 
cjalizacja i esencjalizacja pojęć określających to, co nieformalne, powoduje ich wzajemną nieprzystawalność (i że nie da się nieraz ich ze sobą porównywać). W przypadku badań nad nielegalną wycinką lasów w Indonezji okazało się na przykład, że w chwili narzucenia państwowych regulacji (nacjonalizacja) lasy zaczęto wycinać w jeszcze bardziej „rabunkowy” sposób (Kanbur 2009: 4), m.in. z powodu szybko organizowanej wewnątrz struktur państwa korupcji: dychotomia formalne - nieformalne wciąż ulega w ten sposób zatarciu i badacze w ogóle napotykają raczej jej bardzo kontekstowe i bardzo doraźne użycia (Guha-Khasnobis, Kanbur, Ostrom 2006).

Wskazywałem już, że to, co nieformalne, pojawia się szczególnie wyraziście w studiach nad postsocjalizmem. Kiedy sięgałem w trakcie moich poprzednich badań do analiz materiałów z lat PRL-u, trafiałem na opisy grup zamkniętych, dzielących się przywilejami i nielegalnymi dostępami do różnego rodzaju dóbr; z fabryk, w których pracowano, zdobywano materiały budowlane, opakowania, żywność, surowce, półprodukty leżące w magazynach, a wynoszenie $z$ hal produkcyjnych tych dóbr było jednocześnie usprawiedliwiane jako „słuszne” i „dla ludzi” (zob. m.in. Tymiński 2002: 123-126). Przyzwolenie na tego typu praktyki łączyło się w latach PRL-u z budowaniem w małych grupach, „klikach” poczucia, że uzyskiwanie korzyści dla najbliższych kręgów jest wartością, a praca w państwowych zakładach wręcz zobowiązuje do „załatwiania” najróżniejszych dóbr (wynoszono albo załatwiano na Śląsku np. „haś”, rodzaj pustaka żużlowego służącego do budowy domów; do tej pory wiele produktów np. z Huty Szkła w Skarżysku-Kamiennej tafia do domów pracowników w okolicznych wsiach za przyzwoleniem zespołu pracowników). Stąd też wielu socjologów pisało o kontynuacji w latach 90. silnych związków wewnątrzwiejskich i następnie wiejsko-robotniczych w grupach krewniaczych i krewniaczo-sąsiedzkich - za dawnymi studiami Edwarda Banfielda (1958; zob. też Tarkowska, Tarkowski 1994) - a w niektórych przypadkach łączyli je ze zjawiskiem ,amoralnego familizmu”.

To nieformalne, ciche rozwiązywanie problemów z pracą i utrzymaniem przywilejów w ciasnym kręgu rodziny czy nawet w małej np. sąsiedzko-rodzinnej grupie w wielu przypadkach uznawano zatem za postawę absolutnie przeciwstawną właściwie funkcjonującemu społeczeństwu, przy czym często źródeł tego stanu poszukiwano w „wyposażeniu mentalnym” ludzi wsi, a więc migrantów przenoszących się masowo w latach PRL-u ze wsi do miast. To między innymi te nieformalne, zażyłe grupy - ludzie trafiający z przeludnionych wsi do zakładów przemysłowych i okołoprzemy- 
słowych osiedli - stawały się przede wszystkim w publicystycznych dyskursach odpowiedzialne za niewłaściwe przemiany, za powstawanie struktur, w których dominują negatywne „residua systemowe”. W analizach socjologicznych zwracano więc uwage na ciasne więzi, pozbawione transparentności i przewidywalności, na wewnętrzne lojalności, na dojścia i znajomości, nawet na mentalne skłonności do gromadzenia przede wszystkim dóbr materialnych (zob. m.in. Szafraniec 2002, Tymiński 2002, Wasilewski 1980, 2012)7. Jak się jednak okazywało w kolejnych etapach moich badań (i badań koordynowanych przez mnie zespołów - Rakowski 2008, Rakowski 2013, Rakowski 2016b), w środowiskach tych, a szczególnie wiejskich, te elementy wyposażenia społecznego moga łączyć się z bardzo pozytywnymi formami współpracy. Są to np. zachowujące swą ciągłość praktyki współdziałania w ochotniczych strażach pożarnych (Plińska 2008), w wiejskich zespołach sportowych, w kołach gospodyń wiejskich ${ }^{8}$, które w nowych warunkach tworzyły nie tylko przestrzenie współpracy, ale i nieformalne zręby zamkniętego, cichego obiegu wiedzy i praktyki wzajemnego popierania się?. Tu zatem, wbrew temu, co mówi się o nieobecności kompetencji czy praktyk obywatelskich ${ }^{10}$ na wsi, napotykamy spontaniczne formy organizacji i wspólpracy, przy czym zwykle mają one swoje korzenie w historii, w formach samoorganizacji wiejskiej takich jak: „okółki”, straże

\footnotetext{
${ }^{7}$ Były one często przedstawiane jako pierwsza przeszkoda na drodze do lokalnego rozwoju i budowania w przyszłości swej pozycji przez młodych ludzi. Środowiska potransformacyjnej wsi przedstawiane były więc jako „balast”, „residuum systemowe” (Szafraniec 2002), „hamulcowi modernizacji” (Majcherek 2012), przeciwieństwo obywatelskości (Halamska 2015), a więc to, co jakoś oporne i dysfunkcyjne w pespektywie zmiany społecznej i „odbudowy” społeczeństwa.

${ }^{8}$ Możemy tu szczególnie obserwować kontynuację wzorów wspólnot kobiecych - kół gospodyń wiejskich, które nie miały przecież swego jasno zdefiniowanego zakresu funkcji i działania, nawet w PRL-u. W nieformalnej postaci przetrwały one całą transformację i wciąż działały, by w końcu podłączyć się do gminnych ośrodków kultury albo jako twory osobne, stowarzyszeni, albo żeby trwać przy nielicznych kółkach rolniczych (zob. Mencwel, Milczewska, Wiśniewski 2014).

9 Te formy, często krytykowane jako przejaw nepotyzmu (vide „afera taśmowa” w PSL z roku 2012), sięgają bowiem przy tym, jak uważam, w przeszłość do dawnych i silnych form współdziałania. Prace historyków, takie jak studia Eweliny Szpak (2013) czy Dariusza Jarosza (1998), pokazuja na przykład, że jest to wręcz pewna ciągłość kulturowa, że to specyficzny i nieformalny charakter organizacji wiejskich, a jednocześnie też wskazują moment tworzenia się na wsi, w latach PRL-u, struktur przeciwdziałania odgórnym i niekorzystnym zmianom. Możemy w końcu też śledzić działania o charakterze typowej wiejskiej, nieformalnej samopomocy, której przekrojowego opisu można szukać chociażby w studium o współdziałaniu we wsi Potakówka Marii Biernackiej (1962). Opisywane są tam, choć w nieco anachronicznym, a chwilami wręcz propagandowym stylu, działania w ramach chłopskich spółdzielni, organizacji młodzieżowych, ochotniczej straży pożarnej, kółek rolniczych czy kół gospodyń wiejskich - a więc wszelkich wymiarów samorzutnego, spontanicznego tworzenia się struktur pomocy i samoorganizacji, szczególnie od okresu międzywojennego, poprzez czas wojny, do pierwszej dekady PRL-u.

${ }_{10}$ Stąd pojawiały się w latach 90. wyobrażenia „ostoi inteligenckości” odpowiedzialnej za, jak pisał Kazimierz Krzysztofek, „społeczne zadanie wsparcia samoorganizacji, społeczeństwa obywatelskiego, które z różnych przyczyn jest u nas słabe” (zob. Iłowiecka-Tańska 2011: 33).
}

\section{/ 196 STANRZECZY 1[10]/2016}


wiejskie, wspólne odbudowy domów po pożarach i wiele innych, opisanych np. przez Marię Biernacką (1962). W ten sposób odsłania się bardzo złożona architektura funkcjonowania współczesnych wspólnot wiejskich, nieraz bardzo skonfliktowanych, ale wypełnionych właśnie cichą, zamkniętą aktywnością społeczną i polityczną, dotyczącą w szczególności rozstrzygnięć tego, co we wsi wspólne i co dotyczy także samorządowych instytucji (zob. Najda, Rakowski 2015). Znajdujemy też odniesienia do pewnej oddolnej, żywiołowej podmiotowości społecznej, związanej zarówno w latach PRL, jak i obecnie m.in. z funkcjonowaniem wiejskich budynków publicznych, budowanych niegdyś w „czynie społecznym” i wciąż w ramach „czynu” naprawianych i remontowanych (Pisarzewski 2008, Rakowski 2013, 2016a).

W obszarach poradzieckich takie nieformalne więzi, ulokowane np. w świecie biurokratów, opisywane były przez Caroline Humphrey (2010) i Alenę Ledeneva $(1998,2006)$ jako swego rodzaju kontynuacja świata społecznego wewnątrz komunistycznego państwa. Nie znaczy to jednak w tym przypadku, że jedynie wraz z nadejściem transformacji po socjalizmie ujawniło się dopiero to, co nieformalne, co należy do cichych związków, wzajemnego popierania się i wzajemności. Samoorganizacja i silne więzi wewnątrz zamkniętych kręgów mogą bowiem powstawać niezależnie od socjalizmu i postsocjalistycznej transformacji i sięgać, np. według Ledenevej, jeszcze do przedrewolucyjnej, chłopskiej wsi rosyjskiej i nieformalnych, silnych związków w jej obrębie typu krugovaja paruka (zob. Ledeneva 2004) - odnoszą nas one też do subtelnej gry społecznego wspóldziałania. W charakterystyczny sposób we współpracy takiej znajdziemy dużo zażyłości, familiarności, a także bardzo ambiwalentne zachowania - rytuały „zaznajomienia” czy bycia wewnątrz grupy „wiedzących” opisywane we współczesnych nieformalnych, klikowych strukturach takich jak blat w Rosji czy nawet rodzaj „złodziejskiego prawa” poniatie (Humphrey 2010). W historii postsocjalistycznej transformacji pojawiają się zatem bardzo ambiwalentne sytuacje. Powstaje obieg nieformalności, sfera cichych przysług, wzajemności, porozumienia ponad regulacjami prawnymi czy instytucjonalnymi. W ten sposób pewien rodzaj solidarności, popierania swoich, maksymalizowania zysków grupy czy wąskiego kręgu rodziny jest odnajdywany w transformujących się społeczeństwach Europy Środkowo-Wschodniej nie tylko jako nowa sytuacja, lecz także kontynuacja i efekt poprzedniego systemu. We współczesnej Rosji, w kręgach handlowo-biznesowych skomplikowana komunikacja wokół blatu i związku przysługi czy wręcz „ekonomia przysług” (economy of favours) opisywane są jako specyficzne i umożliwiające wręcz prowadzenie współczesnego biznesu 
w Rosji (Ledeneva 1998, 2006). Jednocześnie badaczka obszarów poradzieckich Caroline Humphrey (2010) pokazuje, że w poradzieckim życiu nowego biznesu, menedżerów, handlowców (często dawnych dyrektorów kołchozów i fabryk państwowych) mamy do czynienia z ciagłym oscylowaniem pomiędzy sympatią i zażyłością z jednej strony, a interesownością i negocjacją z drugiej (zob. też Lonkila 1997); podobnie też z oscylowaniem w ogóle pomiędzy tym, co formalne, uregulowane a tym, co nieformalne, omijające regulacje. Łączy się to też z ciagłością w społeczno-kulturowej egzystencji państwa-instytucji: w czasach Związku Radzieckiego i podobnie w czasach współczesnej Rosji państwo i ludzie są w znacznie mniejszym stopniu osobnymi i przeciwstawnymi bytami, stąd nieformalne więzi, układy nie są od razu traktowane jako funkcjonujące na zewnątrz państwa, ale w sposób niejako nieformalny - wewnątrz niego (państwo, aparat biurokratyczny zawiera zatem w sobie relacje międzyludzkie, życie społeczne i stąd nieformalność naturalnie „mieści się” w państwie - zob. Humphrey 2010). Alena Ledeneva (2011) przedstawia te działania wynikające ze „znajomości" jako obszary nie tylko cichego i bardzo umiejętnego sterowania transakcjami ekonomicznymi, lecz także jako bardzo bogaty system komunikowania tego, co społeczne, zrozumiałe, co często rozumie się „bez słów”, za pomoca , mrugnięcia okiem”. Ledeneva pisze tu o pewnej zażyłości komunikacyjnej na każdym poziomie zamożności - o „rozumiejących uśmieszkach”, „,zytaniu pomiędzy wierszami”, przy czym są to sytuacje komunikacyjne umoźliwiające z jednej strony pewne poczucie panowania nad sytuacja, bycia zorientowanym w grze społecznej, z drugiej jednak wiążą się z pewną mistyfikacja, poczuciem niepewności, nieznajomości reguł (czy też poczucia nieumiejętnego ich stosowania). Pojawia się zatem pewna ambiwalencja obecna w sposobie działania i organizowania się, są to skomplikowane reguły, znaczenia, czasem wręcz odruchowe, a przy tym takie działanie jest trudne, chwilami nieprzewidywalne, wymagające pewnej sztuki postępowania.

Jednocześnie pojęcie tego, co nieformalne i co przykuwa uwagę w badaniach etnograficznych, jest szczególnie blisko spontanicznych procesów społecznej, oddolnej organizacji. W badaniach Agnieszki Halemby (2011) nad instytucjami domów kultury w obszarach poradzieckich w Kosz-Agacz na Ałtaju okazało się na przykład, że właściwie działalność tej instytucji wypełniona jest przede wszystkim nieformalnymi wydarzeniami, spontanicznymi kursami tańca, próbami ujgurskiego zespołu, przy czym jednocześnie sprawozdawano zupełnie inne wydarzenia kulturalne, które właściwie nie dochodziły do skutku. $Z$ wielu pragmatycznych powo-

\section{/ 198 STANRZECZY 1[10]/2016}


dów dom kultury był nieformalnym centrum kultury (czyli czymś, o czym w ramach strategii partycypacyjnych można by marzyć), wszystko to było jednak nieformalna, nierejestrowaną działalnością, a oficjalne sprawozdania zawierały zupełnie co innego - szereg równie intensywnych, ale nieistniejących wydarzeń. Halemba (2011: 109) przywołuje tu interpretacje tych przemian w analizach Alexeja Yurchaka. Jest to według niego społeczny akt reprodukowania formy życia instytucji, ale z reinterpretacją znaczenia; to „heteronimiczne przesunięcie”, jak pisze Yurchak (2003), przekraczające nawet coś co nazywane może być formą oporu albo symulacji czy „markowaniem działania”, to swoista kontynuacja społecznych ideałów „życia radzieckiego", tyle że w oddolnej, spontanicznej, niewidzialnej formie.

To, co nieformalne, jest więc dlatego istotnym w badaniach etnograficznych miejscem, obszarem społecznej praktyki, ponieważ to tam przecina się to, co jest regularnym działaniem, osadzonym w instytucjonalnych i prawnych ramach, z tym, co jest żywiołowym, spontanicznym przewrotnym działaniem (w którym podmioty wytwarzają refleksyjny komentarz do tego, co ich otacza i z czym się mierza). W tym znaczeniu pisał o oddolnej, spontanicznej praktyce i wyobraźni społecznej, choć w zupełnie innym kontekście, Paul Willis (1977, 2005), kiedy badał grupę uczniów zawodówek i szkół średnich w środkowej Anglii lat 70., pochodzących z robotniczych rodzin. Pokazywal jak „faceci” (the lads), manifestacyjnie ignorowali i prześmiewali instytucję szkoły i same wzorce edukacyjne, ale była to dla niego jednak pewna forma organizowania się poprzez właśnie pewną wspólnotowa ,sztukę życia”, jak to nazywał, a więc poprzez proces umiejscawiający aktywnie podmioty wewnątrz społecznej struktury, wewnątrz codziennych nacisków, wykluczeń, wewnątrz codziennych wydarzeń. „Sztuka życia” jest więc dla niego w ten sposób pewnym społecznym mikroprocesem, zawierającym reguły twórczości, podobnym nieco do „poetyki społecznej” Herzfelda (2007), pełnym cichej ekspresji komentarzem do instytucjonalnej i społecznej presji (to „poemat doświadczenia” wtopiony w strukturalną pozycję klasy, grupy czy jednostki). W pewnym momencie ten silny dynamizm życia społecznego, ,społeczna łamigłówka” jak powiedziałby jeszcze Charles Mills, wyznacza więc po prostu ośrodki społecznej i kulturowej produktywności, pełne ukrytych, cichych kompetencji i formujących w ogóle na nowo to, co społeczne.

Jest to też dobrze widoczne w studiach nad procesami modernizacyjnymi w krajach globalnego Południa, a w szczególności w antropologicznych studiach programów rozwojowych i pomocy rozwojowej udzielanej przez duże agendy międzynarodowe (Crewe, Harrison 2002, Mosse 2005). 
W słynnym studium Jamesa Fergusona (1994) projektu rozwojowego realizowanego przez Bank Światowy w Lesotho widać, że ta nieformalna sfera działania w raportach pozostaje zwykle w cieniu, zostaje wyciszona, a przynajmniej zlekceważona. Ferguson opisał akurat to, co działo się w Lesotho, w południowej Afryce, ale pokazał tam pewien ważny moment, w którym agendy i instytucje pomocowe zaczynają unieważniać to, co nieformalne ${ }^{11}$, nie dostrzegając tego, co łączy się nawet z lokalną grą polityczna, z samoorganizacją lokalnych środowisk (planiści nie uznawali znaczenia lokalnych komitetów, grup, struktur partii). Ten wyobrażony brak podmiotowości społecznej, obecny też $\mathrm{w}$ interpretacjach przemian w Polsce i obszarach poradzieckich, pomija zatem to, co niezwykle istotne, a czego nazwać i scharakteryzować w pełni się nie da, ową ,sztukę nieformalnego". Jest to moment, w którym jednocześnie odsłania się to, w jaki sposób powstają olbrzymie zasoby i zdolności poszczególnych środowisk do reprodukcji i do transformacji, ale także do przewarzania i poddawania refleksji struktur, z którymi się mierzą, kiedy działają na własną rękę w nieprzewidywalny sposób. W pewnych sytuacjach mamy zatem do czynienia nie tyle z jakimś jednoznacznym „balastem modernizacyjnym” nie poddającym się regulacjom, ile z koniecznością nazwania i uchwycenia w pojęciach tego, co nieformalne, co wypełnia życie społeczne i łączy się z najbardziej skomplikowanymi procesami samoorganizacji i regeneracji społecznej.

\section{/// Nieformalne we współczesnej Mongolii}

Transformacja mongolska po socjalizmie różni się bardzo od procesów liberalizacji i cichych przekształceń społecznych dokonujących się w sąsiadujących współczesnych Chinach (zob. m.in. Yan 2009; Riley 2012) czy w chińskiej Mongolii Wewnętrznej (zob. Sneath 2000). W dużym stopniu różni się również od tego, co dzieje się w byłych republikach radzieckich i rdzennych, azjatyckich okręgach autonomicznych Federacji Rosyjskiej (zob. m.in. Humphrey 2010, Smyrski 2008, Szmyt 2012). W przejściu od mongolskiej gospodarki centralnie planowanej ${ }^{12}$ do gospodarki wolnorynkowej i społeczeństwa żyjącego w demokracji bardzo wyraźnie widać, jak trudne do zrozumienia i skomplikowane sensy współdziałania powstają na

\footnotetext{
${ }^{11}$ W przypadku Lesotho hodowla bydła została uznana za wiodące (oficjalnie) źródło zarobkowania, nie wzięto pod uwagę natomiast nieformalnych wyjazdów miejscowej ludności na roboty do Kapsztatdu i innych miast RPA

${ }^{12}$ Ukształtowanej mimo wszystko bardzo lokalnie i inaczej niż gospodarki ZSSR (zob. Tangad 2013).
} 
styku tego, co historyczne, dotyczące skolektywizowanej gospodarki pasterskiej, centralnie sterowanej, i nowej potransformacyjnej rzeczywistości, w której nastała „era rynku”, zah zeel (Humphrey, Sneath 1999, Wheeler 2004). Szczególnie interesujący jest tu sposób współdziałania i „sztuka nieformalnego", a więc całe spektrum zachowań i form organizacyjnych, które prowadzą od tego, co może być potraktowane początkowo jako dzialanie „mętne”, wyobrażane jako rodzaj nepotyzmu i korupcji, oparte na więziach, znajomościach, „dojściach”, relacji rodzinno-towarzyskich, aż do form samoorganizacji i wzajemnego popierania się. Stają się one tutaj może nawet bardziej widoczne poprzez kontekst mongolski, specyfikę i idiomy kulturowe, w których są zanurzone. Tutaj także pojawia się podobny dyskurs modernizacyjny, który to, co nieformalne, rozpoznaje jako „balast”, zagrożenie dla dalszego rozwoju społecznego i gospodarczego.

Pokazuje to dobrze David Sneath (2003) w analizie obrazu przekształceń gospodarczych organizacji pomocowych, w orbicie których znajduje się współczesna Mongolia, a więc ponownie Bank Światowy czy Azjatycki Bank Rozwoju. Tym, co wymaga sformalizowania i uregulowania, jest tutaj ziemia i dostęp do niej - według ekspertyz rozwojowych nadanie własności spowoduje większą dbałość i lepsze zarządzanie terenami zarówno pasterskimi, jak i miejskimi. Brak systemu własności sprywatyzowanej ziemi czy w ogóle - nieruchomości - jest tutaj widziany jako przeszkoda czy obciążenie, hamujące procesy rozwojowe i transformacyjne. Znów jednak pomija się to, co nieformalne i co jest jednym z centrów mongolskiego mechanizmu funkcjonowania społecznego. David Sneath (2003) pokazuje, że podział ziemi jest w Mongolii podziałem użytkowania ziemi i łączy się z bardzo skomplikowanym, pasterskim systemem współużytkowania pastwisk i „,czasowym użytkowaniem” - istnieje w ten sposób możliwość poszukiwania nowych terenów do wypasu i jednocześnie wspólistnienie wielu rodzin i grup pasterskich na jednej przestrzeni. „Czasowe użytkowanie” i współwłasność są zatem też pewną osią nieformalnego, zwyczajowego podziału prac, dostępu do ziemi, nawet do dóbr: takich jak samochody, maszyny, sklepy czy mieszkania. Tworzą z jednej strony nieformalny system używania tego, co wspólne - pozwalający na wymuszenia, przesuwanie granic, zajmowanie pastwisk, ale z drugiej strony tworzą te $\dot{z}$ coś, co można by nazwać za Pfaffenbergerem „systemem społeczno-technicznym" (Sneath 2003: 446, zob. także Pfaffenberger 1992), łączącym się przede wszystkim ze skomplikowanym użytkowaniem ziemi i organizowaniem się pasterzy czy użytkowników wspólnych dóbr. Co istotne, w ogóle przemiana tego, co nieformalne, w formy samoorganizacji społecznej 
i w jej ambiwalentne struktury wspierania się nawzajem wiąże się zarówno z historią transformacji mongolskiej, jak i z wcześniejszą forma pasterskiej organizacji Mongolii przedrewolucyjnej. Morten Pedersen (2007), badacz mongolskiej transformacji, pokazuje, że pojawia się w niej nowa sfera nieformalnych grup i związków. Wcześniej jednak należy zauważyć, jak bardzo zmienił się rynek dóbr i usług i jak zmieniły się jego zasady. W latach 90. pojawiła się w Mongolii wolność gospodarcza, otworzono duże bazary i targowiska. Handlarze zaczęli walczyć o stoiska, opłacać usługi „silnych ludzi” i „dużych szefów” (tom bosses), ale to pozwoliło im na zdobywanie względnie niewielkimi kosztami stoisk bazarowych. Po kilku latach pojawiły się nowe targowiska, mniej chaotyczne, ze względnie zaplanowana przestrzenią. Handlujący Mongołowie zaczynają wtedy podlegać znacznie bardziej wymagającym korporacjom zarządców stoisk, stowarzyszeniom kupców, które w nieformalny sposób za pomoca przedstawiania złych opinii o poszczególnych handlarzach (a czasem wprost korumpowania innych dostawców i hurtowników utrudniających lub umożliwiających im dostęp do rynku) wymuszają coraz większe opłaty za miejsce do handlu. Jednocześnie tworzą się tam ,rodziny”, grupy zrzeszające handlujących poszczególnymi towarami, na przykład mąka do wyrobu mongolskich makaronów, które tworzą wspólnoty wzajemnego wsparcia i negocjacji transportu, dostaw, miejsc handlowych. Powstają w ten sposób stopniowo nieformalne regulacje i zasady ,ludzi mąi”” (gurilchinguud), którzy pozostając w dobrych relacjach z kupcami - zarządcami, hurtownikami, dostawcami - są w stanie stworzyć sensowny, przynoszący zyski obrót i zarazem wspólnotę broniąca swych interesów. Aby jednak wejść do tej grupy, trzeba wykazać się z początku siłą charakteru, odpornościa, zderzyć się z niechęcią innych uczestników tego „pola” handlu na wielkomiejskim, mongolskim bazarze. Pedersen opisuje tu historię handlarki Sary, która po roku znoszenia szykan, gróźb, utrudniania dostępu do pośredników i informacji została uznana za należąca do grupy, a inni handlowcy pogratulowali jej uporu i otworzyli na jej cześć butelkę wódki (Pedersen 2007: 68).

Relacje w nowo tworzących się związkach i grupach współpracy pokazuja zatem charakter mongolskiej transformacji, ale jednocześnie mówia bardzo dużo o sposobach funkcjonowania samoorganizujących się grup i ich sposobach nieformalnego działania ekonomicznego (i zarazem pozaekonomicznego). Jest to o tyle istotne, że faza chaotycznego handlu na targowiskach, na ulicach miast (przez lata w Ułan Bator na ulicach stali handlarze $z$ tanim telefonem podłączonym do sieci internetowej i paczkami papierosów, sprzedający rozmowy telefoniczne) związana jest ze skłonno- 
ścią Mongołów do sytuowania drobnego handlu w przestrzeni liminalnej, granicznej, związanej $z$ wchodzeniem $w$ relacje $z$ handlem prowadzonym przez chińskich kupców, których się obawiano. Co więcej, to chińscy kupcy mieli niegdyś niemal wyłączne prawo do handlu w Mongolii i jednocześnie też do handlu z mieszkańcami Chin (z którymi też w dalekiej przeszłości Mongołowie na przemian walczyli i handlowali). Na tym tle jednak znów powstała organizacja przypominająca złożony „system społeczno-techniczny" o skomplikowanej współzależności kilku rodzin i ich stad. Zależności te były tak skomplikowane, że nie rozwijano nadmiernie stad pojedynczej rodziny, tak by wspólny wypas i przepędzanie zwierząt były wydajniejsze (Potkański, Szynkiewicz 1993, Szynkiewicz 1981). Pojawiała się tu nieco inna, bardziej wspólnotowa ekonomia czy raczej szacowanie i praktykowanie wspólnego, bardzo tradycyjnego przedsięwzięcia. Tego typu zależności i idea współpracy są jednak na tyle silnym mongolskim idiomem organizacyjnym, że odnajdujemy go w wielu innych miejscach, a ujawniają się właśnie w studiach nad przemianami transformacyjnymi, gdzie z jednej strony, rodzi się zupełnie nowy mongolski rynek i jednocześnie nowy obszar tego, co nieformalne, z drugiej zaś, odsłania się dawny tradycyjny układ współpracujących grup koczowników, posiadających swoje własne doświadczenia i wyobrażenia o handlu i rynku. Doświadczenia te wynikają zwykle z relacji z chińskimi kupcami, z pewnego uzależnienia od ich towarów i wielowiekowego przeciwstawiania oraz łączenia praktyk handlowych i rynkowych z ideami fundującymi pasterską czy krewniacza formę współdziałania.

W trakcie transformacji mongolskiej pojawia się zatem to, co sięga z jednej strony do bardzo głębokiego wyposażenia kulturowego, a z drugiej do mechanizmów tworzenia się tego, co nowe, nieprzewidywalne, spontaniczne. W przejściu od centralnie sterowanej pararadzieckiej gospodarki do funkcjonowania w warunkach wolnorynkowych i demokratycznych, jak pokazuje badaczka współczesnej Mongolii Oyungerel Tangad (2013), ukazuje się to, co bardzo lokalne, mongolskie, idiomatyczne i co poczattkowo może być uznawane za przejaw omijania państwa prawa - to praktyki widziane jako korupcja, formy nepotyzmu, popierania swoich, a także budowanie nieformalnego, a przez to trudnego do zrozumienia współdziałania. W przeciwieństwie do praktyk europejskich państwowości, w których to, co nieformalne, lokowane jest poza państwem i poza prawem, w Mongolii i w Azji Centralnej to, co nieformalne, istnieje niejako wewnątrz państwa i wewnątrz prawa. Tangad, za Krzysztofem Gawlikowskim, pokazuje, że inaczej niż w Europie, gdzie ludzie poddawani są nakazom państw inge- 
rujących w ich życie i zmuszeni są te nakazy wciąż kontrolować i odpierać, państwo w Azji Centralnej, a w szczególności w Mongolii, jest uznanym rządcą i uprawnionym „pojemnikiem” dla życia społecznego - nie budzi tak negatywnych emocji, obaw, poczucia, że trzeba jego władzę ograniczać. Według Oyungerel Tangad jest w tym zawarta też pewna lokalna kosmologia, wizja zhierarchizowanych bytów, tworzących porządek, który powinien być wciąż odtwarzany i przywracany; dysharmonia ma tutaj właściwie zawsze złe konsekwencje i przynosi nieszczęścia. Stąd państwo jest źródłem energii, która przynosi dobre, dynamiczne życie, nadaje mu pozytywny obrót, jest źródłem siły życiowej dla poszczególnych uczestników i obywateli (Tangad 2013: 226). Cieszy się nieustającym autorytetem, ale mieści się w nim też to, co w Europie jest na zewnątrz państwa i prawa - to, co nieformalne. Tangad pokazuje więc, że wchodząca w demokrację Mongolia tworzy na nowo swój aparat prawny i państwowy, ale jednocześnie zawiera on w sobie cały czas nieformalny, pozaprawny sposób załatwiania spraw, takich jak ugody pomiędzy zwaśnionymi stronami (sądy umożliwiają według Mongołów często mniej „sprawiedliwe” rozstrzygnięcia niż lokalne autorytety - jest wtedy miejsce na łapówki i „dojścia”). Rozporządzenia prawne są więc często ulotne, modyfikowalne, można je obejść i „załatwić” to obejście. Mówi się, że prawo w Mongolii „ważne jest jedynie trzy dni", a później zasady państwa są oddawane nieustannemu rozpuszczaniu, naginaniu, omijaniu; przesuwane są granice własności ziemskich, wykupywane „dojścia” do wykładowców uniwersyteckich, pojawiają się dziurawe ustawy lobbowane i forsowane przez biznesmenów. Państwo, pokazuje Tangad, wypełniane jest w ten sposób nieformalną logika, jego zasady są, jak się często mówi, „mongolizowane”, czyli stopniowo stają się podatne na wpływy i relacje międzyludzkie. „Dojścia” do polityków, prokuratorów, do policji, do lekarzy są niemal powszechnie wykorzystywane.

W pewnym momencie pojawia się w ten sposób wrażenie wszechobecnej korupcji, nepotyzmu, wykorzystywania miękkich kontaktów międzyludzkich do załatwiania wszelkich formalnych i nieformalnych spraw (takie wrażenie miała np. ewangelicka misjonarka wiele lat pracująca w Mongolii na terenie, gdzie prowadziłem badania, znająca lokalne uwarunkowania). Tu jednak, jeśli spojrzymy uważniej, można dostrzec, że wkraczamy w obszar odmiennego i skomplikowanego sposobu funkcjonowania tkanki społecznej i kulturowej Mongolii, i jak łatwo to, co międzyludzkie, może być źródłem zarówno pozytywnych relacji i więzi, jak i instrumentalnym działaniem na rzecz własnej korzyści, wymuszonym omijaniem reguł, zniewalaniem za pomoca korupcji i sieci o charakterze nepotyzmu. Oyungerel 
Tangad (2013) i David Sneath (2006) pokazuja, że w momencie zmiany ustroju na demokratyczny pojawiają się problemy z korupcją, klientelizmem, z wykorzystywaniem znajomości, że stają się lepiej widoczne: wielu Mongołów ma poczucie, że w państwie komunistycznym korupcji właściwie nie było i że pojawienie się wolnego rynku i zwielokrotnione używanie gotówki (monetyzacja) spowodowały pojawienie się np. łapówkarstwa. Osobnym rozdziałem jest tutaj gwałtowny rozwój górnictwa mongolskiego (węgiel, miedź, złoto) i płynące z niego olbrzymie zyski - licencja na posiadanie kopalni jest załatwiana, wykupywana, sa to olbrzymie, ciche transakcje, które stają się też treścia popkultury. W jednym z najnowszych filmów sensacyjnych, aspirujących też do sztuki filmowej, rozgrywka między młodymi bohaterami toczy się o licencji na kopalnię. Od kilku lat o kraju mówi się z przymrużeniem oka, „Mine-golia”"13. Szczególnie Sneath pokazuje także, że relacje, w której wykorzystuje się „dojścia” i „znajomości”, by uzyskać prawo do transakcji (znane sa powszechnie ustawy forsowane przez np. eksporterów mięsa czy twórców prywatnych szpitali), są czymś innym niż powszechne załatwianie transportu jurty i sprzętów gospodarskich ciężarówką znajomego przy przekoczowaniach ze stadami zwierzat, co łączyło się z wypiciem lokalnie wyprodukowanej butelki wódki i było uspołeczniającą budową relacji wzajemności (Sneath 2006: 94). Wiąże się to z mongolskim zwyczajem nakazującym przy różnych okazjach wręczanie prezentów - uczniowie wręczają je swoim nauczycielom, także później - w rocznice ukończenia szkoły, pracownicy - swoim szefom, kiedy zachorują, rodziny obdarowuja się nawzajem przy spotkaniach. Zimą rodziny pasterskie zaopatrują swoich krewnych w duże ilości mięsa, a latem w sery i produkty mleczne (dar zwany idesh). Sam byłem świadkiem, jak podczas podróży z grupa torguckich biznesmenów obdarowana została prokurator z Ułan Batoru (z centralnej prokuratury mongolskiej): w mieście Ałtaj na naszej drodze do miasteczka Bułgan, przy granicy z Chinami, gdzie prowadzę badania, czekali na nią wystrojeni pracownicy miejscowej okręgowej prokuratury. Domagano się przerwania podróży, po czym ugoszczono nas w ich biurach. Po wykwintnym posiłku miejscowi prokuratorzy, mocno wzruszeni, wręczyli prezent - dwie duże butelki likieru zapakowane odświętnie w wielkie, żółte opakowanie (znaczne, duże, robiące wrażenie,

\footnotetext{
${ }^{13}$ Ironizująca gra słów Mine (kopalnia) i golia wiąże się z lokowaniem i otwieraniem wielu nowych kopalń w Mongolii, już od kilkunastu lat, związanych przede wszystkim z wydobyciem miedzi, boksytów, złota czy też węgla kamiennego. Jest to kontrowersyjne źródło wzbogacenia dla wielu lokalnych kręgów biznesu, dla zagranicznych korporacji, dla państwa i urzędników państwowych, a ,własna kopalnia” to np. częsty motyw obecny w popularnych mongolskich filmach sensacyjnych.
} 
tom goj), a obdarowana przyjęła je z godnością i czymś w rodzaju blasku szczęścia na twarzy.

\section{/// Przysługi, „wybielanie rąk” i mongolskie kosmologie współdziałania}

Ktoś mógłby pomyśleć, że to dziwna sytuacja - dotyczy przecież prokuratorów we współczesnej Mongolii, tropiących przede wszystkim przestępstwa gospodarcze. Obdarowywanie ważnych znaczących postaci, ale tak samo ludzi szanowanych, silnych, znaczących, jest jednak najczęściej w tym przypadku sposobem uczczenia, uhonorowania kontrahenta czy zwierzchnika, co nazywane jest „wybieleniem rąk”, gar cajgach. Oznacza to uhonorowanie, namaszczenie, okazanie szacunku; nie jest żadnym, jak można by pomyśleć na gruncie polskim, „wybielaniem”, tj. zacieraniem jakiegoś nieformalnego, „podejrzanego" układu; jest właśnie jego odsłonięciem i docenieniem, jest to „właściwe” zachowanie (biel to też kolor odświętny - w wielu ceremoniach, także religijnych, używa się białej chusty hadag), o takim znaczeniu aktu wręczania podarunku piszą zarówno Oyungerel Tangad, jak i David Sneath. „Podczas gdy w języku polityki stosuje się wyraz korupcja awigal, który ma zdecydowanie negatywną konotację, w życiu codziennym używa się przede wszystkim pojęcia gar cajgach - wybielić ręce, mającego bardzo pozytywne znaczenie, określającego wręczenie darów w celu załatwienia konkretnej sprawy" (Tangad 2013: 233). Sneath (2006) zwraca uwagę, że jest to rodzaj uhonorowania, który wiąże się z potwierdzaniem swej roli i wagi swych zobowiązań, choć rzeczywiście ostatnio pojęcie to stopniowo rozszerza swoje znaczenie i staje się ambiwalentne, czasem jest ono eufemizmem dla łapówki, szczególnie w miastach, choć tu raczej używa się jednak heel habuul i avigal („łapówka”, „korupcja”) albo jeszcze inaczej - gar bundruuleh („obciążyć ręce”). Rozmówcy Sneatha kwalifikują te działania bardzo intuicyjnie i podają, że np. powyżej kwoty 100 dol. mamy raczej do czynienia z „obciążeniem rąk” niż ich „wybieleniem”.

Co istotne, Sneath stara się odejść dalej w swoich rozważaniach od podziału na pozytywne obdarowanie i negatywne korumpowanie i wskazuje na potrzebę odejścia od wyobrażeń ekonomicznych związanych z transakcjami i ogólnie - wymiana. Dostrzega on tu raczej wymiar nieformalnego materializowania się relacji międzyludzkich i osiągania poprzez wręczanie darów i realizowanie przysług (,załatwianie sprawy”) nie tylko korzyści albo wymiernego efektu, ale przede wszystkim właśnie budowania czy osiagania pewnej życiowej pozycji, zrealizowania pewnego społecznego 
zobowiązania (,zobligowania”). Zamiast transakcji (transacting) - wymiany, przekazu dóbr i usług - Sneath (2006: 98) pisze o osiaganiu/budowaniu roli społecznej (enacting). Wręczanie daru (beleg), dostarczanie mięsa, żywności (idesh), pomoc dla rodziny i znajomych - to zatem sposoby budowania relacji i pozycji, budowania swej roli społecznej. Co więcej, choć przekaz pieniędzy może wzmacniać poczucie „przekupywania” - wzajemne usługi i dary, kiedy zostaną zmonetyzowane (a więc wraz z wejściem powszechnego używania pieniędzy w czasie transformacji), mogą stać się po prostu transakcją. Istnieją dwa sposoby traktowania pieniędzy, negatywny, gdy są uważane za „brudne”, „obciążające ręce”, „skalane”, np. pochodzące ze sprzedaży ukopanego złota w biedaszybach (High 2011), albo pozytywny jako „mleczne”, „weselne”, „wybielające”. Samo wręczanie pieniędzy jest traktowane szczególnie, przykłada się je do czoła w geście podziękowania, często dodaje do materialnych prezentów - wódki, materiału, bombonierki. Nierzadko rozmienia się je na drobniejsze nominały, by fizycznie było ich jak najwięcej (na weselu torguckim rozsypywano je na darowanym dywanie, na ubiorze, na beli materiału - potem zsypywano zwitki tugrików do wielkiego worka). Sama monetyzacja nie jest więc procesem wskazującym jednoznacznie na pojawienie się korupcji i łapówek, czyli na to, że coś, co kiedyś załatwiało się za pomocą wymiany przysług, barteru, teraz zostało przełożone na kwoty pieniędzy i dalej pozwala na załatwianie spraw zupełnie poza granicami regulacji biurokratycznych. Raczej cały czas pozostajemy w sferze współdziałania na poziomie nieformalnej (i nieekwiwalentnej) wymiany zobowiązań, osiąania i realizowania swej pozycji, pomocy, gry, w której pieniądze traktowane są bardziej jako rytualne dary, przedmioty niosące symboliczne „kwanty życia”, uruchamiające pozytywny przebieg wydarzeń i przywołujące powodzenie (zob. m.in. Wasilewski 1980).

Sneathowi nie chodzi tu zatem tylko o podział na transakcje i ustanawianie/odgrywanie roli społecznej, ale wskazuje on także na pewną obecność działania na poziomie organizującego się oddolnie społeczeństwa. „Oliwienie" relacji obywatel-państwo za pomocą przysług, prezentów, pomocy, wzajemne przekraczanie reguł tworzą środowisko działania i daja poczucie radzenia sobie, posiadania przyjaciół. Tangad opisuje takie formy biurokratyczne uznawane przez Mongołów za przyjazne, które pozostawiaja zawsze pewne pole manewru ${ }^{14}$. Urzędy europejskie są uznawane za „zimne” i „oschłe” (Tangad 2013). Na lotnisku widziałem, jak mieszka-

${ }^{14}$ Negocjowana jest np. waga bagażu na lotnisku. Można grzecznie poprosić, by podano jego niższą wagę; inna sprawa, że pracownik lotniska kilka tygodni wcześniej akurat negocjującej osobie pozostawił pod opieką podczas lotu dwójkę dzieci ze swej rodziny podróżujących do Ułan Bator. 
niec miasta Chowd wręczył nieznajomej pasażerce paczuszkę z numerem telefonu z prośbą o przekazanie jej w Ułan Bator jego krewnym. Takie całkowite zaufanie nieznajomym jest bardzo częste w Mongolii. Podobnie Humphrey (2012: 24) pokazuje, że robienie drobnych i większych przysług w urzędach, w instytucjach państwowych, w codziennych kontaktach to pewien utrwalony sposób załatwiania sprawy, stąd np. brytyjscy urzędnicy wydają się Mongołom niezwykle oschli i nieprzejednani. Zrobienie przysługi, okazana pomoc to zatem pewien utrwalony i ugruntowany odruch - sposób funkcjonowania społecznego.

Z pewnego punktu widzenia takie zachowania mogą zatem otworzyć drogę do zupełnie innego pojmowania samego działania nieformalnego przy dogadywaniu spraw i robieniu przysług. Bardzo ciekawie pisze na ten temat Caroline Humphrey (2012: 26-28). Przysługi, jak twierdzi, nie są tylko sposobem uzyskania usługi czy tego, co chcemy, ale są raczej sposobami realizowania pewnej etyczności swego postępowania, pewnej sztuki bycia wdzięcznym lub pomocnym, hojnym, szczodrym, i w ten sposób budowana jest sztuka bycia „kimś” w oczach innych, o czym pisał także Adam Smith, i poprzez to bycia soba. To budowanie „estymy wobec siebie samego”. Stąd nie jest to tylko paraekonomiczna transakcja, w której nawet „oliwione” są transakcje. W robieniu przysługi najczęściej nie chodzi o liczenie na rewanż, twierdzi Humphrey, ale raczej o pewną ,moralną estetykę” tego aktu (moral aesthetic of action), ,wielu ludzi - pisze - woli użyć przysługi jako formy działania, nawet jeżeli oficjalna droga załatwienia sprawy jest łatwo dostępna. Działanie jako przysługa daje naddatek podzięki i błogosławieństwa dla każdej praktycznej funkcji działania i czyni je niemożliwym do skalkulowania" (Humphrey 2012: 23). Tutaj docieramy do kluczowej kwestii. Otóż w przeciwieństwie do wyobrażenia pewnych „niepisanych reguł postępowania" w świecie nieformalnego przyjęcie współpracy i zrobienie przysługi jest ruchem ryzykownym - buduje to pewna pozycję, może być realizacja zobowiązań rodzica, krewnego czy nawet urzędnika państwowego, ale często jest ruchem wiodącym w nieznane - nie ma żadnych gwarancji, że będzie uznane i że mechanizm wzajemności zadziała symetrycznie. Może za to - jak pokazuje Humphrey - być iskrą inicjująca nowe relacje i związki, może otwierać i utrwalać więzi, tworzyć środowisko społeczne, choć jest to ciągle seria skomplikowanych zagrań i przedsięwzięć. Jest w tym coś zarówno koniecznego, jak i heroicznego - to, jak pisze Humphrey, „zwykli bohaterowie" wybierający zawsze drogę dookoła (tj. poprzez nieformalne układy). „Sztuka nieformalnego” jest sztuką nie tylko osiagania celów, ale sztuką budowania pozycji, budowania siebie w oczach innych, to wzmac- 
nianie siebie/osoby poprzez wzmacnianie roli ,ja” jako członka wspólnoty, w której działa się z pewną sztuką i umiejętnością. W tym sensie to wybór i zarazem sposób tworzenia kręgu, budowania środowiska, ale osiagany za pomoca podjęcia wyzwania, dokonania sprytnych, „skrętnych” działań, poza tym, co regularne. To droga do tworzenia - jak pisze Humphrey nieformalnych sieci znajomych i krewnych na zasadzie ciagłego podejmowania ryzyka przysług i odpowiadania na nie (odwzajemnienie daru czy przysługi nie jest pewne i może być w końcu różnie rozegrane). To sytuacja gry wymagającej nieustannej zręczności, to prowokowanie powodzenia, to również moment, w którym osiaga się pozycję w sieci i buduje poczucie nabudowywanej podmiotowości. W tym sensie to, co nieformalne, łączy się z wymiarem kosmologicznym, z budowaniem poprzez skomplikowaną architekturę przysług i więzi „siły powodzenia”, wyposażenia w siłę życiową (süld), atrakcyjności (zob. Humphrey, Ujeed 2012, Tangad 2013: 105-121). Jeśli będzie to związane ze sprytem, siłą, odwagą, wyobrażenie takie będzie przedstawiane jako „koń wietrzny” (chijmor), siła wznosząca ku górze, promieniująca na innych, też - pociagająca (koń z rozwiana grzywa to częsty motyw graficzny - to np. logo flagowych linii lotniczych Mongolii). Oprócz indywidualnych sił danej osoby (süld) i jej prezentacji czy realizacji (chijmor), poprzez organizowanie życia, dokonywanie przysługi odwzajemnień powstaje jednak też pewna siła społeczna, gromadząca ludzi wokół silnych, sprytnych, twórczych osobowości - w tym przypadku będzie to już bardziej element siły życia zwanej bujan - to fortuna i bogactwo nagromadzone jako sieć relacji (a nie szczęśliwie pojawiających się dóbr czy pieniędzy, to raczej oddaje pojęcie chis ₹ig), przyjaciół, uczynków i właśnie przysług, „często można spotkać określenie bujantaj carajtaj chun, osoba z twarza bujan, co oznacza, że takiej sobie można zaufać, gdyż można oczekiwać od niej postawy dobrej, moralnej, pozytywnej" (Tangad 2013: 118 $)^{15}$. Odsłania się tu pewna specyficzna droga budowania swego powodzenia poprzez innych, poprzez robienie czegoś z innymi, rodzina (młodzi, obecnie trzydziesto-, czterdziestoletni przedsiębiorcy zwykle mają po dziesięcioro i więcej rodzeństwa, i to z nimi wspólpracuja), znajomymi (przez całe życie Mongołów celebrowane są związki uczniów i uczennic z tej samej klasy znacznie bardziej niż np. w Rosji, gdzie też mówi się wiele o odnoktasnikach).

\footnotetext{
15 To moment budowania dobrego obrotu spraw poprzez gromadzenie potęgi/mocy związku i wymiany z innymi ludźmi - tak jak w powiedzeniu mongolskim przytaczanym przez Oyungerel Tangad: „człowiek, który ma znajomych, jest wielki jak step, a ten, który nie ma znajomych, jest mały jak dłoń” (2013: 221).
} 
Oyungerel Tangad pisze o Mongołach używających w urzędach zwrotów „wujku”, „ciociu”, szukających wspólnych krewnych, oferujących podarki. Częsta to praktyka zwracać się z nieformalną prośbą do urzędników, do administratorów obór publicznych, a jednocześnie z „cichymi” prośbami udawać się do braci i sióstr w Ułan Bator o przyjęcie dzieci do bursy, młodych do pracy, o pożyczkę na uruchomienie nowego biznesu. Są to zachowania zawierające w sobie pragnienie czynienia relacji pararodzinnymi, „mongolskimi”, co nie znaczy, że są one zawsze korzystne albo przyjazne - wciąż noszą w sobie ryzyko niedopowiedzenia i właściwie nigdy nie gwarantują czegoś takiego jako „obligatoryjny zwrot” (Humphrey 2012). Jeden z braci zdolnego i rzutkiego biznesmena z Bułganu (południowe stoki Ałtaju) organizował dla niego budowę hotelu przez kilka miesięcy, przy czym odpłatą miało być użyczenie mieszkania w Ułan Bator („,czasowe użytkowanie" - to często podstawowa forma własności w Mongolii, zob. Empson 2011). Budowa się zakończyła, brat-wykonawca został bez pracy, mieszkań biznesmena w Ułan Bator na razie używa ktoś inny, choć studiuje tam syn wykonawcy i wspiera go po cichu brat-biznesmen. Podobną nieekwiwalencję znajdziemy w historii środowiska samego Bułganu; hotel, kiedy został zbudowany, posłużył przede wszystkim jako baza dla gości gminy, która zorganizowała razem z lokalnym klubem biznesmenów trzydniowe wygłaszanie eposu Dżangar. Na to wydarzenie mieli być zaproszeni goście: rodacy - Torguci z Sinkiangu, Australii i Kałmucji. Zarówno biznesmeni, jak i władza ofiarowali darowizny, dokładali z własnych środków, by święto Torgutów z Bułganu - i ich duma - miało godną oprawę i by wszyscy goście byli należycie przyjęci. Kiedy tam byliśmy, zaraz po tym wydarzeniu wszyscy lokalni organizatorzy byli poważnie zadłużeni, hotel stał pusty, prawdopodobnie zadłużony był też budżet całego somonu, a urzędnicy odpoczywali na urlopach po wielotygodniowej pracy. Wzajemne nieformalne świadczenie przysług jest więc właśnie z jednej strony nieprzewidywalne, z drugiej spontaniczne, obejmuje energia całe grupy ludzi, lokalne, mongolskie środowiska - Bułgańczycy na przykład zbierają się co roku, aby zorganizować wielkie święto, a zarazem ceremonię religijna - czczenie gór, odprawianie rytuałów, wyścigi koni, walki zapaśników, koncerty z tańcami Bijelgee i Ich agsal w domu kultury i niekończące się wręczanie odznaczeń najlepszym obywatelom: pasterzom, nauczycielom, kierownikom, przedsiębiorcom. Poprzez udział i darowizny następuje tu jednak nie tylko ogłaszanie czyjejś siły, pozycji, bujanu i nawet osobistego chijmoru, „ruchu w górę”, lecz także nakręca się spiralę możliwego i upragnionego powodzenia, promieniującego na wszystkich dookoła (na tablicach przed 
urzędami pojawiają się wtedy długie spisy darczyńców, zwykłych ludzi, przedsiębiorców, firm, instytucji).

\section{/// Sztuka nieformalnego: niejednoznaczne ośrodki samoorganizacji}

Transformacje systemowe i ich społeczne, żywiołowe efekty w Polsce, Europie Środkowo-Wschodniej czy we współczesnej Mongolii ukazuja zróżnicowane zjawiska „sztuki nieformalnego”. Próba ich zrozumienia to trudny dla badacza moment, w którym rzeczywistość społeczną często przesłaniaja zachodniocentryczne pojęcia i dyskursy modernizacyjne, które z nieufnością wydobywaja na wierzch to, co nieuregulowane: ekonomię nieformalną, znajomości, „familizm”, próby korupcji i wprowadzania krewniaczo-znajomościowej solidarności do wolnego rynku pracy i do świata formalnej administracji. Wielu interpretatorów życia społecznego widzi w tym zagrożenie, blokadę drogi do rozwoju gospodarczego i przede wszystkim do powstawania nowoczesnego społeczeństwa obywatelskiego, przy czym jest ono wyobrażane często jako pewien normatywny wzór, o czym pisze m. in. Karol Kurowski (2013: 31-38; bardziej krytyczne omówienie tego stanowiska zob. Hann, Dunn 1996, Zarycki 2009). Szczególnie często taki dyskurs dotykał środowisk wiejskich, obarczanych „zacofaną” formą „familizmu”, trwałością wiejskich zależności, zwyczajem popierania swoich. Stąd brak rozwiniętego społeczeństwa obywatelskiego diagnozowało w Polsce wielu badaczy i praktyków, twórców organizacji pozarządowych, wskazując na konieczność odtwarzania i budowania niemal od zera kompetencji obywatelskich (Borowiec 2006, Pacześniak 2007, Iłowiecka-Tańska 2011: 14-34). Można tu jednak przecież wykazać, że sfera działania nieformalnego jest niczym innym, jak pewnym sposobem „radzenia sobie" i budowaniem na nowo wspólnot (mających jednak często też pewną ciagłość socjologiczną i historyczna) w nowych, potransformacyjnych warunkach, i odwrotnie - tu właśnie rozpoznać formy tego, co obywatelskie (Rakowski 2013).

Aby uchwycić i nazwać „to, co nieformalne”, i pokazać, jak sfera ta może się stawać ośrodkiem organizowania się pewnych idei życia społecznego czy po prostu „dobrego życia” (choć pozostaje ona przy tym czymś otwartym i ambiwalentnym), sięgałem tutaj do różnych teorii i badań prowadzonych w obszarach poradzieckich, ale przede wszystkim do materiału mongolskiego, gdzie to, co nieformalne, w szczególny sposób wypełnia i współtworzy struktury zarówno oddolnych organizacji, jak i państwo- 
wej administracji. Okazuje się, że w tym przypadku zachodzi coś znacznie ważniejszego - nieformalność ta jest pewną sztuką działania, niepewną, ryzykowna, jednocześnie ludzką i bliską realnych relacji czy bliską budowanych i podtrzymywanych ról społecznych. Może ona uruchomić nowe związki i nowe środowiska, ale może być też forma przestępstwa, realnej korupcji czy łapówkarstwa. Jest to sfera rugowana i piętnowana przez dyskursy modernizacyjne, które uniemożliwiają dostrzeżenie leżących u podstaw tych zachowań dawnego, nieformalnego podziału prac i zobowiązań, czy w końcu skomplikowanego systemu wzajemnej pomocy pasterskiej (czy obecnie handlowej), pozwalającej na przetrwanie w najbardziej niesprzyjających okolicznościach (Potkański, Szynkiewicz 1993, Sneath 2003). Jest jednak powszechna formą organizowania się, zdobywania ,ważnych” znajomych i jest zarazem formą sięgania daleko w stronę kosmologicznych, wyobrażonych procesów powodzenia, fortuny, osiagania szczęścia. Przeplata się tutaj to, co nieformalne, z tym, co powstaje w obrębie aparatu państwa. Jeśli więc myślimy też o granicy pomiędzy korupcją, „załatwieniem sprawy" a współpracą i nawiązywaniem relacji (czy osiaganiem pozycji) a wielu znanych mi biznesmenów mongolskich współpracuje z lokalnymi władzami, przy czym po jakimś czasie pełnią oni też funkcje polityczne i samorządowe - to możemy mówić w tym przypadku o bardzo porowatej i w sensie pozytywnym (a może nawet ,partycypacyjnym”) przepuszczalnej granicy pomiędzy państwem, jego instytucjami a społeczeństwem i jego praktykami. W zaskakujący sposób za pomocą obiegu przysług i „tego, co nieformalne”, powstaja wtedy nie tyle „obciążenia modernizacyjne”, tj. zjawiska określane mianem „nepotyzmu”, „korupcji”, „układów-znajomości”, ile właśnie bardzo ważne zręby tworzenia się lokalnych form rozwoju i obywatelskości we współczesnej Mongolii, których idiomy związane są z azjatycką, mocno odmienną logiką życia społecznego. Cały czas odsłania się jednak w ten sposób ten obszar życia społecznego, który domaga się zrozumienia i uchwycenia w pojęciach. To właśnie to, co należy do sztuki nieformalnych działań, nabiera cech nie tylko tego, co oddolne i spontaniczne, ale tego, co może łączyć się w ogóle z energią regeneracji społecznej, pewną oddolną sztuką społecznej organizacji, a nawet z iskrą wolności.

Bibliografia:

/// Aretxaga B. 2003. Maddening States, „Annual Review of Anthropology”, nr 32, s. 393-410. 
/// Banfield E. 1958. The Moral Basis of a Backward Society, Free Press.

/// Biernacka M. 1962. Potakówka. Wieśpowiatu jasielskiego 1890-1960. Z badań nad wspótdzৃiałaniem, Ludowa Spółdzielnia Wydawnicza.

/// Borowiec P. 2006. Gtówne pržeszeody w realizacji idei społeczeństwa obywatelskiego, [w:] Czas spoteczeństwa obywatelskiego: miedzy teoriq a praktyka, red. B. Krauz-Mozer, P. Borowiec, Wydawnictwo Uniwersytetu Jagiellońskiego, s. $145-160$.

/// Buchowski M. 1996. The Shifting Meanings of Civil and Civic Society in Poland, [w:] Civil Society: Challenging Western Models, red. E. Dunn, C. Hann, Routledge, s. 77-95.

/// Cichocki S. 2006. Metody pomiaru „,szarej strefy”, „Gospodarka Narodowa", nr 1-2, s. 37-62.

/// Crewe E., Harrison E. 2002. Whose Development? An Ethnography of Aid, Zed Books.

/// Coombe R. 2005. Objects of Property and Subjects of Politics. Intellectual Property Laws and Democratic Dialogue, [w:] Law and Anthropology. A Reader, red. S.F. Moore, Blackwell Publishing, s. 111-123.

/// Ferguson J. 1994. The Anti-Politics Machine. „Development”, Depoliticization and Bureaucratic Power in Lesotho, University of Minnesota Press.

/// Galor Z. 2011. Gospodarka formalna i nieformalna a zróżnicowanie społeczne, [w:] Uwarunkowania różnic społecżno-ekonomicznych, red. K. Leszczewska, J. Truszkowska, Wyd. PWSIiP, s. 87-106.

/// Guha-Khasnobis B., Kanbur R., Ostrom E., red. 2006. Linking the Formal and Informal Economy: Concepts and Policies, Oxford University Press.

/// Halamska M. 2015. Chtop to nie obywatel. Z Marią Halamską rozmawia Ł. Pawłowski, „Kultura Liberalna”, 2 (314).

/// Halemba A. 2011. Three Houses of Culture in Kosh Agach: Accounting for Culture work in a Changing Political Setting, [w:] Reconstructing the House of Culture: Community, Self and the Makings of Culture in Russia and Beyond, red. J.O. Habeck, B. Donahoe, Berghahn Books, s. 97-116.

/// Hann Ch., Dunn E., red. 1996. Civil Society. Challenging Western Models, Routledge. 
/// Hart K. 2005. Formal Bureaucracy and the Emergent Forms of the Informal Economy. Research Paper nr 11, United Nations University.

/// Hart K. 2008. Between Bureaucracy and the People: A Political History of Informality, [w:] Markets for Peace? Working Paper nr 27, Danish Institute for International Studies.

/// Henig D., Makovicky N., red. 2016. Economies of Favour after Socialism. A Comparative Perspective, Oxford University Press.

/// Herzfeld M. 2007. Zażytość kulturowa. Poetyka społecæna w państwie narodowym, tłum. M. Buchowski, Wydawnictwo Uniwersytetu Jagiellońskiego.

/// Herzfeld M. 2009. The Cultural Politics of Gesture. Reflections on the Embodiment of Ethnographic Practice, „Ethnography”, nr 10(2), s. 131-152.

/// High M. 2011. Polluted Money, Polluted Wealth. Emerging Regimes of Value in the Mongolian Gold Rush, „American Anthropologist”, nr 40, s. 676-688.

/// Humphrey C. 2010. Koniec radzৃieckiego życia. Ekonomie życia codžiennego po socjalizmie, tłum. A. Halemba, Wydawnictwo Marek Derewiecki.

/// Humphrey C. 2012. Favors and "Normal Heroes". The Case of Postsocialist Higher Education, „HAU: Journal of Ethnographic Theory”, nr 2(2), s. 22-41.

/// Humphrey C., Sneath D. 1999. The End of Nomadism? Society, State and the Environment in Inner Asia, Cambridge University Press.

/// Humphrey C., Ujeed H. 2012. Fortune in the Wind. An Impersonal Subjectivity, „Social Analysis”, nr 2 (56), s. 152-167.

/// Iłowiecka-Tańska I. 2011. Liderzy i dzৃiałacze. O idei trzeciego sektora w Polsce, WUW.

/// Jarosz D. 1998. Polityke władz komunistycznych w Polsce w latach 1948-1956 a chtopi, Wydawnictwo DIG.

/// Kanbur R. 2009. Conceptualizing Informality. Regulation and Enforcement, Cornell University.

/// Kideckel D. 2002. The Unmaking of an East European Working Class, [w:] Post-socialism: Ideals, Ideologies and Practices in Eurasia, red. Ch. Hann, Routledge, s. 114-132. 
/// Knudsen I. H., Frederiksen M.D. red. 2015. Ethnographies of Grey Zones in Eastern Europe. Relation, Borders and Invisibilities, Anthem Press.

/// Kurowski K. 2013. Samoorganizacja w wielkomiejskim slumsie. Przyktad Limy, WUW.

/// Ledeneva A. 1998. Russia's Economy of Favours. Blat, Networking and Informal Exchange, Cambridge University Press.

/// Ledeneva A. 2004. The Genealogy of Krugovaya Poruka: Forced Trust as a Feature of Russian Political Culture, [w:] Trust and Democratic Transition in Post-Communist Europe, red. I. Markova, Oxford University Press, s. 85-108.

/// Ledeneva A. 2006. How Russia Really Works. The Informal Practices that shaped Post-Socialist Politics and Business, Cornell University Press.

/// Ledeneva A. 2011. Open Secrets and Knowing Smiles, „East European Politics and Societies", nr 25(4), s. 720-736.

/// Linstroth J. 2010. Maddening Legalities: Subjectivities and the Law, „Journal of Legal Anthropology", nr 2, s. 247-258.

/// Lonkila M. 1997. Informal Exchange Relations in Post-Soviet Russia: A Comparative Perspective, „Sociological Research Online”, nr 2(2), http://www.socresonline.org.uk/soresonline/2/2/9.html.

/// Łapiński K., Peterlik M., Wyżnikiewicz B. 2014. Szara strefa w polskiej gospodarce, raport, Instytut Badań nad Gospodarką Rynkowa.

/// Majcherek J. 2012. Hamulcowi modernizacji, „Gazeta Wyborcza”, 08.08.2012.

/// Mencwel J., Milczewska K., Wiśniewski J. 2014. Koła Gospodyń Wiejskich - nie tylko od kuchni, raport, Pracownia Badań i Innowacji Społecznych „Stocznia”.

/// Mosse D. 2005. Cultivating Development. An Ethnography of Aid Policy and Practice, Pluto Press.

/// Najda W., Rakowski T. 2015. „Królowie boiska”. Samoorganizacja wiejskiego klubu sportowego, [w:] Oddolne tworzenie kultury. Perspektywa antropologiczna, red. K. Dudek, S. Sikora, IEiAK UW, s. 51-61.

/// Pacześniak A. 2007. Bariery obywatelskości w polskim społeczeństwie po 1989 roku, [w:] Europa obywateli. Polskie spoteczeństwo obywatelskie in actu, red. W. Bo- 
kajło, A. Wiktorska-Święcicka, Oficyna Wydawnicza Atut - Wrocławskie Wydawnictwo Oświatowe, s. 143-153.

/// Pedersen M. 2007. From „Public” to „Private” Market in Postsocialist Mongolia, „Anthropology of East Europe Review”, nr 25, s. 64-71.

/// Pfaffenberger B. 1992. Technology and Social Change, „Annual Review of Anthropology", nr 21, s. 491-516.

/// Pisarzewski T. 2008. Wspólnota wiejska - przemiany, [w:] Lokalnie: animacja kultury/community arts, red. I. Kurz, Instytut Kultury Polskiej. Uniwersytet Warszawski, s. 85-88.

/// Plińska W. 2008. Ochotnicza strażpożarna - klub kultury, [w:] Lokalnie: animacja kultury/community arts, red. I. Kurz, Instytut Kultury Polskiej. Uniwersytet Warszawski, s. 89-92.

/// Przychodzeń J., Przychodzeń K. 2009. Szara strefa a nierówności dochodowe w gospodarkach postsocjalistycznych, „Master of Business Administration”, $\mathrm{nr} 2$, s. $75-81$.

/// Rakowski T. 2008. Antropologiczne przesuniecie perspektywy i animacja kultury. Warsztaty badawcze, [w:] Lokalnie: animacja kultury/community arts, red. I. Kurz, IKP UW, s. 76-81.

/// Rakowski T. 2009. Lowcy, zbieracze, praktycy niemocy. Etnografia człowieka zdegradowanego, Wydawnictwo słowo/obraz terytoria.

/// Rakowski, T. 2013. Alternatywne historie myśli socjologic₹nej. Driatania, imaginacje, pragnienia, [w:] Etnografia/animacja/sztuka. Nierozpoznane wymiary rozwoju kulturalnego, red. T. Rakowski, NCK, s. 122-138.

/// Rakowski T. 2015. Historia mówiona i źródta etnograficzne jako ,wiedża pewna". Pr₹ypadek potransformacyjnej bistorii Torgutów w zachodniej Mongolii oraz historii wsi Broniów w centralnej Polsce, „Rocznik Antropologii Historii”, nr 8.

/// Rakowski T. 2016a. Interior Spectacles. The Art of the Informal among Bootleg Miners in Watbrzych, Poland, [w:] Economies of Favour after Socialism: A Comparative Perspective, red. N. Makovicky, D. Henig, Oxford University Press, s. $161-180$.

/// Rakowski T., red. 2016b. Moduł Driatanie w kulturze, [w:] Oddolne tworzenie kultury. Wielostanowiskowe studium porównawcze, praca zbiorowa, Instytut Etnologii i Antropologii Kulturowej UW 2016, http://kulturaoddolna.pl/ dzialanie-w-kulturze/; dostęp: 15.09.2016. 
/// Riley N. 2012. Laboring in Paradise: Gender, Work, and Family in a Chinese Economic Zone, Springer Press.

/// Smyrski Ł. 2008. Ajdyn znaczy ksieżyc. Narody potudniowej Syberii, Wydawnictwo DiG.

/// Sneath D. 2000. Changing Inner Mongolia. Pastoral Mongolian Society and the Chinese State, Oxford University Press.

/// Sneath D. 2003. Land-Use, the Environment and Development in Post-socialist Mongolia, „Oxford Development Studies”, nr 4(31), s. 441-459.

/// Sneath D. 2006. Transacting and Enacting: Corruption, Obligation and the Use of Monies in Mongolia, „Ethnos”, nr 71, s. 89-112.

/// Szafraniec K. 2002. Polskie residuum systemowe, czyli pytanie o role wsi i chtopów w procesach przeksz̨tałceń ustrojowych, „Kultura i Społeczeństwo”, nr 4, s. 81-107.

/// Szmyt Z. 2012. Azja u bram. Badania nad migracjami Buriatów w Rosji, Wydawnictwo Nauka i Innowacje.

/// Szpak E. 2013. Mentalność ludności wiejskiej w PRL. Studium żmian, Wydawnictwo Naukowe Scholar.

/// Szynkiewicz S. 1981. Rodzina pasterska w Mongolii, Zakład Narodowy im. Ossolińskich.

/// Szynkiewicz S. 1993. Mongolia's Nomads Build a New Society Again: Social Structures and Obligations On the Eve of the Private Economy, „Nomadic Peoples”, nr 33, s. 163-172.

/// Szynkiewcz S., Potkański T. 1993. The Social Context of Liberalisation of the Mongolian Pastoral Economy, (raport z badań), nr 4. https://opendocs.ids. ac.uk/opendocs/handle/123456789/2434; dostęp: 21.10.2016.

/// Tangad O. 2013. Scheda po Czyngis Chanie. Demokracja po mongolsku, Wydawnictwo Trio.

/// Tarkowska E., Tarkowski J. 1994. „Amoralny familizm” czyli o dezintegracji spolecznej w Polsce lat osiemdziesiatych, [w:] Wladza i spoleczeństwo w systemie autorytarnym, red. J. Tarkowski, IFiS PAN, s. 263-281.

/// Tymiński M. 2002. Funkecjonowanie klik w akeładach przemystowych (19501970), „Kultura i Społeczeństwo”, nr 4, s. 109-131. 
/// Wasilewski J. S. 1980. Podarować - znależć - zgubić - zbładzić. Niektóre kategorie jezyka symbolicznego zwiazane z opozycja życie - śmierć, „Etnografia Polska", nr (24) 1, s. 283-303.

/// Wasilewski J. 2012. Jesteśmy potomkami chtopów, zprof. Jackiem Wasilenskim rozmawia Marta Duch-Dyngosz, „Znak” nr 684, s. 14-17.

/// Wheeler A. 2004. Moralities of the Mongolian «Market»; A Genealogy of Trade Relations and the Zah Zeel, „Inner Asia”, nr 6, s. 215-238.

/// Willis P. 1977. Learning to Labour. How Working Class Kids Get Working Class Jobs, Columbia University Press.

/// Willis P. 2005. Wyobraźnia etnograficzna, tłum. E. Klekot, Wydawnictwo Uniwersytetu Jagiellońskiego.

/// Yan Y. 2009. The Individualization of Chinese Society, Bloomsbury Publishing.

/// Yurchak A. 2002. Entrepreneurial Governmentality in Post-Socialist Russia: A Cultural Investigation of Business Practices, [w:] The New Entrepreneurs of Europe and Asia, red. V.E. Bonnell, T.B. Gold, M.E. Sharpe, s. 278-324.

/// Yurchak A. 2003. Soviet Hegemony of Form: Everything Was Forever, Until It Was No More, „Comparative Studies in Society and History”, nr 3, s. 480510 .

/// Zarycki T. 2009. O prowincjonalizmie inaczej, [w:] W posఇukiwaniu portretu Polaków, red. J. Szomburg, Instytut Badań nad Gospodarka Rynkowa, s. 55-64.

\section{/// Abstrakt}

W pracy tej chcę pokazać, w jaki sposób antropologiczne rozumienie sfery nieformalności, obszaru spontanicznych i skomplikowanych mechanizmów współdziałania społecznego, może zmieniać się i rozwijać pod wpływem kontekstu badawczego. Zajmuje mnie szczególnie to, co jako działanie nieformalne i balansujące na granicy prawa było rozpoznawane przez badaczy i publicystów jako balast na drodze do właściwego rozwoju społecznego. Dlatego wprowadzam tutaj pojęcie „sztuki nieformalnego”, w którym rozpoznawane moga być także pozytywne kulturowe uwarunkowania nieformalnej współpracy i w ten sposób też samoorganizacji spo- 
łecznej. Następnie analizuję, jak zmienia się użycie tego pojęcia w sytuacji, w której badania odnoszą się do rzeczywistości potransformacyjnej Polski, Europy Środkowo-Wschodniej, obszarów byłego Związku Sowieckiego oraz przede wszystkim - do współczesnej Mongolii. To przejście od polskich doświadczeń do złożonych kontekstów mongolskich jest pewna droga poznawczą, w której na różnych poziomach napotykam konieczność tworzenia nowych, zmieniających się pojęć zdolnych uchwycić i zidentyfikować sferę tego, co nieformalne.

Słowa kluczowe:

sztuka nieformalnego, ekonomia nieformalna, samoorganizacja, ekonomia przysług, Torguci, Mongolia

\section{/// Abstract}

In this article, I show how an anthropological understanding of informality and also spontaneous forms of social collaboration or self-organisation may change and develop when related to the concrete site and particular context of research. I am concerned with how the informal sector is recognised by researchers and as a kind of failure or as something defective which holds back modernisation and development programmes. I introduce the notion of "the art of the informal", which encompasses and underlines some positive aspects of informal collaboration and a certain independent self-organisation. I analyse "the art of the informal" in the contexts of post-socialist Poland, Central-Eastern Europe, the former Soviet bloc, and especially contemporary Mongolia. I try to show that the informal ties existing in local traditions may signify grassroots forms of collaboration and an impulse for self-organisation. At the same time, I show how shifting from the context of postsocialist Europe to the context of contemporary Mongolia requires creating constantly new notions in order to name the informal processes vis-à-vis local cosmologies and imaginaries.

Keywords:

the art of the informal, informal economy, self-organisation, economy of favour, Torghuts, Mongolia 